\title{
FUZZY TIME SERIES DAN ALGORITME AVERAGE-BASED LENGTH UNTUK PREDIKSI PEKERJA MIGRAN INDONESIA
}

\author{
Solikhin $^{1}$, Uky Yudatama ${ }^{2}$ \\ ${ }^{1}$ STMIK Himsya Semarang, Indonesia, ${ }^{2}$ Universitas Muhammadiyah Magelang, Indonesia \\ Email: ${ }^{1}$ solikhin@himsya.ac.id, ${ }^{2}$ uky@post.com
}

(Naskah masuk: 25 Oktober 2018, diterima untuk diterbitkan: 27 Mei 2019)

\begin{abstract}
Abstrak
Perkembangan jumlah Pekerja Migran Indonesia (PMI) program Government to Government $(G$ to $G)$ Jepang bidang perawat (nurse) dan perawat orang berusia lanjut (care worker) mengalami naik turun dari tahun 2008 hingga 2018. Untuk dapat menganalisis jumlah PMI yang mengalami naik turun dengan mengukur perkembangan jumlah PMI saat ini dan memprediksikan kondisi tersebut pada masa mendatang, maka diperlukan model prediksi. Dalam penelitian ini diterapkan model fuzzy time series dengan menggunakan algoritme average-based length. Penentuan panjang interval yang efektif dapat mempengaruhi hasil prediksi yaitu dapat meningkatkan keakuratan yang tinggi dalam fuzzy time series. Hasil proses prediksi PMI program $G$ to $G$ Jepang tahun 2019 bidang nurse diperoleh 43.3, bidang care worker diperoleh 300 dan bidang keseluruhan diperoleh 325. Hasil uji kinerja prediksi PMI program $G$ to $G$ Jepang, menggunakan Mean Absolute Percentage Error (MAPE) adalah $24.27 \%$ untuk bidang nurse dengan nilai akurasi prediksi $20-50 \%$ termasuk dalam kriteria "wajar", bidang care worker $11.29 \%$ dengan nilai akurasi prediksi 10-20\% termasuk dalam kriteria "baik", sedangkan untuk bidang keseluruhan diperoleh $8.41 \%$ dengan nilai akurasi prediksi $M A P E<10 \%$ termasuk dalam kriteria "sangat baik". Berdasarkan hasil prediksi tersebut dapat digunakan sebagai pendukung keputusan bagi manajemen dalam membuat kebijakan terkait persiapan, perencanaan, penjadwalan, penempatan, dan perlindungan terhadap para calon PMI pada masa mendatang. Dengan demikian dapat meningkatkan kualitas kinerja sumberdaya manusia dalam memberikan pelayanan terbaik terhadap para calon PMI program $G$ to $G$ Jepang.
\end{abstract}

Kata kunci: Pekerja Migran Indonesia, G to G Jepang, prediksi, average-based length, fuzzy time series

\section{FUZZY TIME SERIES AND AVERAGE-BASED LENGTH ALGORITHM FOR INDONESIAN MIGRANT WORKERS PREDICTION}

\begin{abstract}
The development of the number of Pekerja Migran Indonesia (PMI) Government to Government programs ( $G$ to $G)$ in Japan in the field of nurses and care workers experienced ups and downs from 2008 to 2018. To be able to analyze the number of PMIs experiencing ups and downs by measuring the development of the current number of PMIs and predicting these conditions in the future, a prediction model is needed. In this study fuzzy time series models are applied using an average-based length algorithm. Determining the length of an effective interval can influence the results of predictions, which can increase high accuracy in fuzzy time series. The results of the PMI program G to G Japan prediction process for 2019 in the nurse field were obtained 43.3, the care worker field was obtained 300 and the overall field was 325. The results of the G to G Japan PMI prediction performance test, using the Mean Absolute Percentage Error (MAPE) were $24.27 \%$ for nurse field with predictive accuracy value of 20-50\% included in the criteria of "reasonable", the field of care worker $11.29 \%$ with a prediction accuracy value of 10-20\% included in the criteria "good", while for the overall field obtained $8.41 \%$ with MAPE prediction accuracy value $<10 \%$ is included in the criteria of "very good". Based on the results of these predictions it can be used as a decision support for management in making policies related to preparation, planning, scheduling, placement, and protection of future PMI candidates. Thus it can improve the quality of the performance of human resources in providing the best service to prospective $G-G$ Japan PMI programs.
\end{abstract}

Keywords: Pekerja Migran Indonesia, G to G Japan, prediction, average-based length, fuzzy time series 


\section{PENDAHULUAN}

UU RI No 18 Tahun 2017 tentang Perlindungan PMI (Pekerja Migran Indonesia), pasal 1 ayat 2 disebutkan bahwa: PMI adalah setiap WNI yang akan, sedang, atau telah melakukan pekerjaan dengan menerima upah di luar wilayah RI dan berdasarkan informasi dari Deputi BNP2TKI (Penempatan dan Direktur Pelayanan Penempatan Pemerintah) menyatakan bahwa Penempatan PMI di Jepang cukup banyak jumlahnya (bnp2tki.go.id, 2018). Jalinan kerjasama antara Indonesia dengan Jepang di bidang penempatan PMI dimulai sejak tahun 2008 khususnya penempatan di bidang keperawatan (nurse) dan perawat untuk orang lanjut usia (care worker) (bnp2tki.go.id, 2018).

Dalam perkembanganya jumlah peminat PMI program $G$ to $G$ ke Jepang di bidang ini dari tahun 2008 hingga 2018 mengalami naik turun (bnp2tki.go.id, 2018), sehingga tidak dapat diketahui secara jelas tentang jumlahnya, untuk itu diperlukan prediksi. Prediksi bertujuan untuk memperkirakan jumlah yang nantinya digunakan sebagai dasar penyusunan rencana bisnis pada suatu perusahaan untuk meningkatkan efektivitas (Heizer dan Render, 2009). Secara umum sistem prediksi dapat digunakan sebagai pendukung keputusan bagi manajemen dalam membuat kebijakan terkait persiapan, perencanaan, penjadwalan, penempatan, dan perlindungan terhadap para calon PMI pada masa mendatang, sehingga diharapkan dapat meningkatkan kualitas kinerja sumberdaya manusia dalam memberikan pelayanan terbaik terhadap para calon PMI.

Berdasarkan uraian di atas, perkembangan jumlah PMI program $G$ to $G$ ke Jepang diperlukan sebuah metode prediksi, untuk itu peneliti mengusulkan fuzzy time series dan algoritme average-based length digunakan untuk memprediksi suatu perkembangan jumlah. Meskipun tergolong sederhana, namun dari hasi uji kinerjanya metode ini lebih akurat serta memiliki tingkat kesalahan (error) yang lebih kecil. Dalam penelitian ini, ingin menjawab suatu pertanyaan yaitu bagaimana fuzzy time series dan algoritme average-based length dapat digunakan untuk memprediksi jumlah perkembangan PMI program $G$ to $G$ ke Jepang dimasa mendatang? serta bagaimana kinerja metode prediksi ini dilihat dari tingkat persentase kesalahannya?

Hasil penilitian ini diharapkan dapat memberikan sebuah kontribusi yang nyata terutama dalam pengembangan suatu metode prediksi yang efektif serta memiliki akurasi lebih baik yang dapat digunakan untuk memprediksi perkembangan suatu jumlah pada masa mendatang, sehingga sangat berguna bagi pemangku kepentingan dalam pengambilan sebuah kebijakan secara cepat dan tepat.

\section{TINJAUAN PUSTAKA}

Berkaitan dengan masalah prediksi beberapa peneliti telah mengusulkan konsep fuzzy time series. Pendahulu Konsep ini adalah Song dan Chissom (Aladag dkk., 2012). Berikutnya bermunculan peneliti lainnya dengan mengusulkan konsep baru untuk memprediksi pendaftaran pada Universitas Alabama, seperti; (Singh dan Borah, 2013; Wang dkk., 2013; Lu dkk., 2015; Bisht dan Kumar, 2016).

Salah satu hal yang sangat penting dalam masalah prediksi adalah penentuan panjang interval yang efektif. Panjang interval sangat mempengaruhi hasil prediksi yakni dapat meningkatkan hasil prediksi secara signifikan. Banyak peneliti melakukan perbaikan terhadap metode dalam fuzzy time series, terkait masalah berikut (Singh dan Borah, 2013):

a) Effective length of interfal (Xihao dan Yimin, 2008; Wang dkk., 2013).

b) Fuzzy logical relationships (Huarng dan Yu, 2012; Anggodo dan Mahmudy, 2016)

c) Defuzzification techniques.

Penerapan fuzzy time series juga digunakan oleh peneliti lainnya untuk memprediksi indeks gabungan Shanghai, algoritme yang digunakan adalah average-based length (Xihao dan Yimin, 2008). Dalam penelitiannya diperkenalkan rata-rata berbasis panjang interval (Xihao dan Yimin, 2008).

\subsection{Fuzzy Time Series}

fuzzy time series pada umumnya terdiri dari tiga tahapan utama seperti; fuzzifikasi, penentuan Fuzzy Logical Relationships (FLRs), dan defuzzifikasi (Aladag dkk., 2012).

Apabila $U$ sebagai himpunan, maka $U=\left\{u_{1} ; u_{2}\right.$; $\left.\ldots ; u_{n}\right\}$. Fuzzy set $A_{i}$ pada $U$ ditentukan oleh $A_{i}=f_{A i}$ $\left(u_{1}\right)=u_{1}+f_{A i}\left(u_{2}\right)=u_{2}+\cdots+f_{A i}\left(u_{n}\right)=u_{n}$; di mana $f_{A i}$ adalah fungsi keanggotaan dari fuzzy set.

$A_{i} ; f_{A i}: U \rightarrow[0 ; 1] . u_{k}$ merupakan bagian fuzzy set $A_{i}$, dan $f_{A i}\left(u_{k}\right)$ merupakan fungsi keanggotaan dari $u_{k}$ to $A_{i}: f_{A i}\left(u_{k}\right) \in[0 ; 1]$ di mana $1 \leq k \leq n$ (Xihao dan Yimin, 2008).

Definisi 1. $Y(t) \quad(t=\ldots ; 0 ; 1 ; 2 ; \ldots)$, merupakan bagian dari R. $Y(t)$ menjadi himpunan yang didefinisikan oleh fuzzy set $f_{i}(t)$. Apabila $F(t)$ terdiri dari $f_{i}(t)(i=1 ; 2 ; \ldots)$; maka $F(t)$ didefinisikan sebagai fuzzy time series pada $Y(t)(t=\ldots ; 0 ; 1 ; 2 ; \ldots)$. (Xihao dan Yimin, 2008).

Definisi 2. Apabila terdapat hubungan fuzzy $R(t-1 ; t)$, seperti $F(t)=F(t-1) \times R(t-1 ; t)$, maka $F(t)$ dinyatakan sebagai $F(t-1)$. Perhatikan bahwa operator dapat berupa max-min, min-max, atau operator aritmatika. Ketika $F(t-1)=A_{i}$ dan $F(t)=A_{j}$ ; relasi antara $F(t-1)$ dan $F(t)$ disebut FLRs yang dilambangkan $A_{i} \rightarrow A_{j}$ : (Xihao dan Yimin, 2008).

Definisi 3. FLRs dengan fuzzy set yang sama di sisi kiri dapat dikelompokkan lebih lanjut ke dalam fuzzy 
logical relationship group (FLRGs). Misal terdapat FLRs seperti berikut ini: (Xihao dan Yimin, 2008).

$A_{i} \rightarrow A_{j l}$

$A_{i} \rightarrow A_{j 2}$;

.....

Maka dapat dikelompokkan ke dalam FLRGs

$A_{i} \rightarrow A_{j 1} ; A_{j 2} ; \ldots$.

Fuzzy set yang sama hanya dapat muncul sekali pada sisi kanan FLRGs.

\subsection{Average-Based Length}

Pendekatan yang didasarkan pada rata-rata selisih pertama, atau disebut panjang rata-rata. Karena rata-rata selisih pertama belum tentu memenuhi heuristik (setidaknya separuh selisih pertama harus direfleksikan), rata-rata berbasis panjang interval ditetapkan menjadi setengah dari rata-rata selisih pertama.

Algoritme Average-Based Length (Xihao dan Yimin, 2008):

1) Hitunglah selisih/perbedaan absolut seluruhnya antara $A_{i}+1$ dan $A_{i}(i=1 ; \ldots ; n-1)$, sebagai selisih pertama dan rata-rata dari selisih.

2) Ambil $\frac{1}{2}$ rata-rata dari langkah pertama sebagai panjang intervalnya.

3) Dari hasil langkah kedua, tentukan basis panjang intervalnya dengan mengacu pada Tabel 1 .

4) Bulatkan panjang sesuai dengan basis yang ditentukan sebagai panjang interval.

\begin{tabular}{cc} 
Tabel 1 Basis Pemetaan \\
(Xihao dan Yimin, 2008) \\
\hline Range & Basis \\
\hline $0.1-1.0$ & 0.1 \\
$1.1-10$ & 1 \\
$11-100$ & 10 \\
$101-1000$ & 100 \\
\hline
\end{tabular}

Untuk menunjukkan seberapa efektif panjang interval dapat ditentukan berdasarkan panjang ratarata, sebagai contoh data time series berikut ini (Xihao dan Yimin, 2008):

30, 50, 80, 120, 100, dan 70 .

Beberapa tahapan dalam penerapan algoritme average-based length (Xihao dan Yimin, 2008):

1) Hasil selisih adalah:

$20 ; 30 ; 40 ; 20 ; 30$

Jadi untuk rata-rata selisih pertama 28.

2) Ambil $\frac{1}{2}$ rata-rata panjangnya: 14 .

3) Dari hasil langkah kedua, panjang interval ditentukan berdasarkan Tabel 1 yaitu berbasis 10.

4) Pembulatan panjang interval 14 dengan basis 10 , yaitu 10. Jadi 10 dipilih sebagai panjang interval.

\section{METODOLOGI}

Metodologi penelitian ini seperti ditunjukkan Gambar 1.

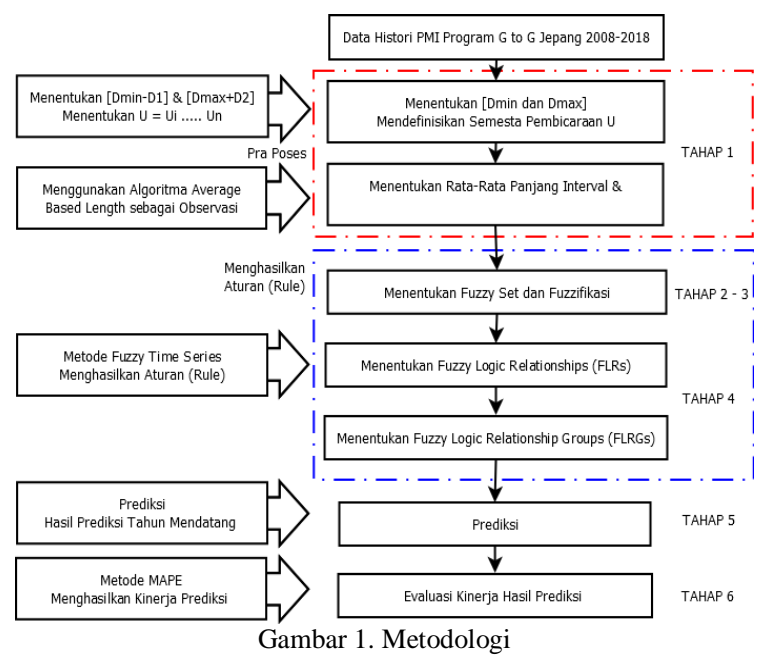

\section{PEMBAHASAN}

Dalam penelitian ini untuk melakukan prediksi dibutuhkan data histori jumlah PMI program $G$ to $G$ Jepang dari tahun 2008 sampai dengan 2018. Fokus data yang digunakan adalah jumlah PMI di bidang nurse, care worker dan bidang keseluruhan (nurse dan care worker) ditunjukkan pada Tabel 2, 3 dan 4.

Tabel 2. Histori PMI Program $G$ to $G$ Jepang Bidang Nurse Sumber : Data Penempatan dan Perlindungan PMI

\begin{tabular}{cc}
\hline Tahun & Nurse \\
\hline 2008 & 104 \\
2009 & 173 \\
2010 & 39 \\
2011 & 47 \\
2012 & 29 \\
2013 & 48 \\
2014 & 41 \\
2015 & 66 \\
2016 & 46 \\
2017 & 29 \\
2018 & 31 \\
\hline
\end{tabular}

Tabel 3. Histori PMI Program $G$ to $G$ Jepang Bidang Care worker Sumber : Data Penempatan dan Perlindungan PMI

\begin{tabular}{lc} 
Tahun & Care worker \\
2008 & 104 \\
2009 & 189 \\
2010 & 77 \\
2011 & 58 \\
2012 & 72 \\
2013 & 108 \\
2014 & 146 \\
2015 & 212 \\
2016 & 233 \\
2017 & 295 \\
2018 & 298 \\
\hline
\end{tabular}

Tabel 4. Histori PMI Program $G$ to $G$ Jepang Bidang Keseluruhan Sumber : Data Penempatan dan Perlindungan PMI

\begin{tabular}{cc}
\hline Tahun & Keseluruhan \\
\hline 2008 & 208 \\
2009 & 362 \\
2010 & 116 \\
2011 & 105 \\
\hline
\end{tabular}




\begin{tabular}{cc}
\hline Tahun & Keseluruhan \\
\hline 2012 & 101 \\
2013 & 156 \\
2014 & 187 \\
2015 & 278 \\
2016 & 279 \\
2017 & 324 \\
2018 & 329 \\
\hline
\end{tabular}

Tahap 1. Penentuan Himpunan dan Interval Sebagai observasi, himpunan $U$ didefinisikan sebagai $\left[D_{\min }, D_{\max }\right]$, di mana $D_{\min }$ dan $D_{\max }$ adalah histori data minimum dan maksimum yang berupa dua bilangan positif.

Berdasarkan histori data PMI $G$ to $G$ Jepang untuk bidang nurse, care worker dan bidang keseluruhan tahun 2008-2018:

Bidang nurse; diketahui $D_{\min }=29$ sedangkan $D_{\max }=$ 173. Jadi himpunan kenggotaan didefinisikan sebagai $U=[20,200]$.

Bidang care worker; diketahui $D_{\min }=58$ sedangkan $D_{\max }=298$. Jadi himpunan kenggotaan didefinisikan sebagai $U=[50,300]$.

Bidang keseluruhan; diketahui $D_{\min }=101$ sedangkan $D_{\max }=362$. Jadi himpunan kenggotaan didefinisikan sebagai $U=[100,370]$.

Perhitungan Average-Based Length

1. Hitung rara-rata dari selisih, maka diperoleh :

Bidang nurse $=31.9$

Bidang care worker $=45.6$

Bidang keseluruhan $=64.3$

2. Ambil $\frac{1}{2}$ rata-rata selisih dari langkah pertama sebagai panjangnya, yaitu:

Bidang nurse $=15.95$

Bidang care worker $=22.8$

Keseluruhan bidang $=32,15$.

3. Rata-rata panjang dari hasil langkah kedua, dapat ditentukan basisnya dengan mengikuti pada Tabel 1, Jadi basis panjang adalah sebagai berikut:

Bidang nurse $=10$

Bidang care worker $=10$

Bidang keseluruhan $=10$

4. Membulatkan panjang masing-masing dari hasil langkah kedua, yaitu: Bidang nurse 15.95 dengan basis 10 menjadi 20. 20 dipilih sebagai panjang interval pada bidang nurse;

Bidang care worker 22.8 dengan basis 10 menjadi 20. 20 dipilih sebagai panjang interval pada bidang care worker;

Bidang keseluruhan 32.15 dengan basis 10 menjadi 30. 30 dipilih sebagai panjang interval pada bidang keseluruhan.

Maka $U$ dapat dipartisi ke dalam panjang interval yang sama yaitu:

Untuk bidang nurse adalah $u_{1, .} . ., u_{17}$, sedangkan nilai tengah interval ini adalah $m_{1}, \ldots$, $m_{17}$, di mana bidang nurse $u_{1}=[20,30], \ldots, u_{17}=$ $[180,190]$.
Untuk bidang care worker adalah $u_{1}, \ldots, u_{13}$, sedangkan nilai tengah interval ini adalah $m_{1}, \ldots$, $m_{13}$, di mana bidang care worker $u_{1}=[50,70], \ldots$, $u_{13}=[290,310]$.

Sedangkan untuk keseluruhan bidang adalah $u_{1}, \ldots, u_{9}$, sedangkan nilai tengah interval ini adalah $m_{1}, \ldots ., m_{9}$, di mana bidang keseluruhan $u_{1}=[100$, $130], \ldots, u_{9}=[340,370]$.

Tahap 2. Penentuan Fuzzy Set

Setiap pengamatan dari linguistik, $A_{i}$, dapat ditentukan oleh interval $u_{1}, \ldots, u_{n}$, sebagai berikut:

\section{Bidang Nurse}

$A_{1}=\frac{1}{u_{1}}+\frac{\frac{1}{2}}{u_{2}}+\frac{0}{u_{3}}+\frac{0}{u_{4}}+\frac{0}{u_{5}}+\frac{0}{u_{6}}+\cdots \frac{0}{u_{16}}+\frac{0}{u_{17}}$

$A_{2}=\frac{\frac{1}{2}}{u_{1}}+\frac{1}{u_{2}}+\frac{\frac{1}{2}}{u_{3}}+\frac{0}{u_{4}}+\frac{0}{u_{5}}+\frac{0}{u_{6}}+\cdots \frac{0}{u_{16}}+\frac{0}{u_{17}}$

$A_{3}=\frac{0}{u_{1}}+\frac{\frac{1}{2}}{u_{2}}+\frac{1}{u_{3}}+\frac{\frac{1}{2}}{u_{4}}+\frac{0}{u_{5}}+\frac{0}{u_{6}}+\cdots \frac{0}{u_{16}}+\frac{0}{u_{17}}$

$A_{17}=\frac{0}{u_{1}}+\frac{0}{u_{2}}+\frac{0}{u_{3}}+\frac{0}{u_{4}}+\cdots+\frac{0}{u_{15}}+\frac{\frac{1}{2}}{u_{16}}+\frac{1}{u_{17}}$

\section{Bidang Care worker}

$A_{1}=\frac{1}{u_{1}}+\frac{\frac{1}{2}}{u_{2}}+\frac{0}{u_{3}}+\frac{0}{u_{4}}+\frac{0}{u_{5}}+\frac{0}{u_{6}}+\cdots \frac{0}{u_{12}}+\frac{0}{u_{13}}$

$A_{2}=\frac{\frac{1}{2}}{u_{1}}+\frac{1}{u_{2}}+\frac{\frac{1}{2}}{u_{3}}+\frac{0}{u_{4}}+\frac{0}{u_{5}}+\frac{0}{u_{6}}+\cdots \frac{0}{u_{12}}+\frac{0}{u_{13}}$

$A_{3}=\frac{0}{u_{1}}+\frac{\frac{1}{2}}{u_{2}}+\frac{1}{u_{3}}+\frac{\frac{1}{2}}{u_{4}}+\frac{0}{u_{5}}+\frac{0}{u_{6}}+\cdots \frac{0}{u_{12}}+\frac{0}{u_{13}}$

$A_{13}=\frac{0}{u_{1}}+\frac{0}{u_{2}}+\frac{0}{u_{3}}+\frac{0}{u_{4}}+\cdots+\frac{0}{u_{11}}+\frac{\frac{1}{2}}{u_{12}}+\frac{1}{u_{13}}$

\section{Bidang Keseluruhan}

$A_{1}=\frac{1}{u_{1}}+\frac{\frac{1}{2}}{u_{2}}+\frac{0}{u_{3}}+\frac{0}{u_{4}}+\frac{0}{u_{5}}+\frac{0}{u_{6}}+\cdots \frac{0}{u_{8}}+\frac{0}{u_{9}}$
$A_{2}=\frac{\frac{1}{2}}{u_{1}}+\frac{1}{u_{2}}+\frac{\frac{1}{2}}{u_{3}}+\frac{0}{u_{4}}+\frac{0}{u_{5}}+\frac{0}{u_{6}}+\cdots \frac{0}{u_{8}}+\frac{0}{u_{9}}$
$A_{3}=\frac{0}{u_{1}}+\frac{\frac{1}{2}}{u_{2}}+\frac{1}{u_{3}}+\frac{\frac{1}{2}}{u_{4}}+\frac{0}{u_{5}}+\frac{0}{u_{6}}+\cdots \frac{0}{u_{8}}+\frac{0}{u_{9}}$

$A_{9}=\frac{0}{u_{1}}+\frac{0}{u_{2}}+\frac{0}{u_{3}}+\frac{0}{u_{4}}+\frac{0}{u_{5}}+\cdots \frac{0}{u_{7}}+\frac{\frac{1}{2}}{u_{8}}+\frac{1}{u_{9}}$ 
Tahap 3. Melakukan Fuzzifikasi.

Dari data time series PMI program $G$ to $G$ Jepang dapat difuzzifikasikan menjadi fuzzy set $A_{i}$ seperti ditunjukkan Tabel 5, 6 dan 7.

\begin{tabular}{|c|c|c|}
\hline Tahun & Data Histori & Fuzzified \\
\hline 2008 & 104 & $A_{5}$ \\
\hline 2009 & 173 & $A_{8}$ \\
\hline 2010 & 39 & $A_{l}$ \\
\hline 2011 & 47 & $A_{2}$ \\
\hline 2012 & 29 & $A_{l}$ \\
\hline 2013 & 48 & $A_{2}$ \\
\hline 2014 & 41 & $A_{2}$ \\
\hline 2015 & 66 & $A_{3}$ \\
\hline 2016 & 46 & $A_{2}$ \\
\hline 2017 & 29 & $A_{l}$ \\
\hline 2018 & 31 & $A_{l}$ \\
\hline \multicolumn{3}{|c|}{ Tabel 6 Fuzzified Bidang Care worker } \\
\hline Tahun & Data Histori & Fuzzified \\
\hline 2008 & 104 & $A_{3}$ \\
\hline 2009 & 189 & $A_{7}$ \\
\hline 2010 & 77 & $A_{2}$ \\
\hline 2011 & 58 & $A_{I}$ \\
\hline 2012 & 72 & $A_{2}$ \\
\hline 2013 & 108 & $A_{3}$ \\
\hline 2014 & 146 & $A_{5}$ \\
\hline 2015 & 212 & $A_{9}$ \\
\hline 2016 & 233 & $A_{10}$ \\
\hline 2017 & 295 & $A_{13}$ \\
\hline 2018 & 298 & $A_{13}$ \\
\hline \multicolumn{3}{|c|}{ Tabel 7 Fuzzified Bidang Keseluruhan } \\
\hline Tahun & Data Histori & Fuzzified \\
\hline 2008 & 208 & $A_{4}$ \\
\hline 2009 & 362 & $A_{9}$ \\
\hline 2010 & 116 & $A_{1}$ \\
\hline 2011 & 105 & $A_{l}$ \\
\hline 2012 & 101 & $A_{l}$ \\
\hline 2013 & 156 & $A_{2}$ \\
\hline 2014 & 187 & $A_{3}$ \\
\hline 2015 & 278 & $A_{6}$ \\
\hline 2016 & 279 & $A_{6}$ \\
\hline 2017 & 324 & $A_{8}$ \\
\hline 2018 & 329 & $A_{8}$ \\
\hline
\end{tabular}

Tahap 4. Menentukan FLRs dan FLRGs.

Berdasarkan penentuan fuzzy set pada Tahap 3, selanjutnya tentukan FLRs, seperti ditunjukkan Tabel 8.

\begin{tabular}{|c|c|c|}
\hline Nurse & Care worker & Keseluruhan \\
\hline$A_{5} \rightarrow A_{8}$ & $A_{3} \rightarrow A_{7}$ & $A_{4} \rightarrow A_{9}$ \\
\hline$A_{8} \rightarrow A_{I}$ & $A_{7} \rightarrow A_{2}$ & $A_{9} \rightarrow A_{l}$ \\
\hline$A_{1} \rightarrow A_{2}$ & $A_{2} \rightarrow A_{1}$ & $A_{l} \rightarrow A_{I}$ \\
\hline$A_{2} \rightarrow A_{l}$ & $A_{1} \rightarrow A_{2}$ & $A_{l} \rightarrow A_{l}$ \\
\hline$A_{1} \rightarrow A_{2}$ & $A_{2} \rightarrow A_{3}$ & $A_{1} \rightarrow A_{2}$ \\
\hline$A_{2} \rightarrow A_{2}$ & $A_{3} \rightarrow A_{5}$ & $A_{2} \rightarrow A_{3}$ \\
\hline$A_{2} \rightarrow A_{3}$ & $A_{5} \rightarrow A_{9}$ & $A_{3} \rightarrow A_{6}$ \\
\hline$A_{3} \rightarrow A_{2}$ & $A_{9} \rightarrow A_{10}$ & $A_{6} \rightarrow A_{6}$ \\
\hline$A_{2} \rightarrow A_{l}$ & $A_{10} \rightarrow A_{13}$ & $A_{6} \rightarrow A_{8}$ \\
\hline$A_{l} \rightarrow A_{l}$ & $A_{13} \rightarrow A_{13}$ & $A_{8} \rightarrow A_{8}$ \\
\hline
\end{tabular}

Dilanjutkan dengan menentukan FLRGs, seperti ditunjukkan Tabel 9.

Tabel 9. FLRGs Bidang Nurse, Care worker dan Keseluruhan

\begin{tabular}{lll}
\hline \multicolumn{1}{c}{ Nurse } & Care worker & Keseluruhan \\
\hline$A_{l} \rightarrow A_{2}, A_{2}, A_{1}$ & $A_{1} \rightarrow A_{2}$ & $A_{1} \rightarrow A_{l}, A_{1}, A_{2}$ \\
$A_{2} \rightarrow A_{l}, A_{2}, A_{3}, A_{1}$ & $A_{2} \rightarrow A_{1}, A_{3}$ & $A_{2} \rightarrow A_{3}$ \\
$A_{3} \rightarrow A_{2}$ & $A_{3} \rightarrow A_{5}, A_{7}$ & $A_{3} \rightarrow A_{6}$ \\
$A_{5} \rightarrow A_{8}$ & $A_{5} \rightarrow A_{9}$ & $A_{4} \rightarrow A_{9}$ \\
$A_{8} \rightarrow A_{1}$ & $A_{7} \rightarrow A_{2}$ & $A_{6} \rightarrow A_{6}, A_{8}$ \\
& $A_{9} \rightarrow A_{10}$ & $A_{8} \rightarrow A_{8}$ \\
& $A_{10} \rightarrow A_{13}$ & $A_{9} \rightarrow A_{1}$ \\
& $A_{13} \rightarrow A_{13}$ & \\
\hline
\end{tabular}

Tahap 5. Prediksi

Dalam melakukan prediksi, aturan yang digunakan adalah sebagai berikut:

Aturan 1: Apabila fuzzy set adalah $A_{i}$, dan FLRGs $A_{i}$ kosong, yaitu $A_{i} \rightarrow$, maka prediksinya adalah $m_{i}$, yang merupakan nilai tengah dari $u_{i}$. ditunjukkan pada rumus 1 (Xihao dan Yimin, 2008).

Forecasting $=m_{i}$

Aturan 2: Apabila fuzzy set adalah $A_{i}$, dan FLRGs dari $A_{i}$ adalah satu-ke-satu, yaitu: $A_{i} \rightarrow A_{j}$, maka prediksinya adalah $m_{j}$, yang merupakan nilai tengah dari $u_{j}$. Ditunjukkan pada rumus 2 (Xihao dan Yimin, 2008).

Forecasting $=m_{j}$

Aturan 3: Apabila fuzzy set adalah $A_{i}$, dan FLRGs dari $A_{i}$ adalah satu-ke-banyak, maka: $A_{i} \rightarrow A_{j 1}, A_{j 2}$ ,..., $A_{j n}$, maka prediksinya adalah rata-rata $m_{j 1}, m_{j 2}$, $\ldots, m_{j n}$, yang merupakan nilai tengah dari $u_{j l}, u_{j 2}$, $\ldots, u_{j n}$, masing-masing. Ditunjukkan pada rumus 3 (Xihao dan Yimin, 2008).

$$
\text { Forecasting }=\frac{\sum_{i=1}^{n} m_{j i}}{n}
$$

Dengan melihat aturan di atas dan Tabel 9, maka perhitungan defuzzyfikasi untuk prediksinya adalah sebagai berikut:

\section{Bidang Nurse}

$A_{1} \rightarrow A_{2}, A_{2}, A_{1}$

$A_{1}=\frac{1}{3}\left(m_{2}+m_{2}+m_{1}\right)$

$A_{1}=\frac{1}{3}(50+50+30)$

$A_{1}=43.3$

$A_{2} \rightarrow A_{1}, A_{2}, A_{3}, A_{1}$

$A_{2}=\frac{1}{4}\left(m_{1}+m_{2}+m_{3}+m_{1}\right)$

$A_{2}=\frac{1}{4}(30+50+70+30)$ 
374 Jurnal Teknologi Informasi dan Ilmu Komputer (JTIIK), Vol. 6, No. 4, Agustus 2019, hlm. 369-376

$$
\begin{aligned}
& A_{2}=45 \\
& A_{3} \rightarrow A_{2} \\
& A_{3} \rightarrow m_{2} \\
& A_{3}=50 \\
& A_{5} \rightarrow A_{8} \\
& A_{5} \rightarrow m_{8} \\
& A_{5}=170 \\
& A_{8} \rightarrow A_{1} \\
& A_{8} \rightarrow m_{1} \\
& A_{8}=30
\end{aligned}
$$

\section{Bidang Care worker}

$$
\begin{aligned}
& A_{1} \rightarrow A_{2} \\
& A_{1} \rightarrow m_{2} \\
& A_{1}=80 \\
& A_{2} \rightarrow A_{1}, A_{3} \\
& A_{2}=\frac{1}{2}\left(m_{1}+m_{3}\right) \\
& A_{2}=\frac{1}{2}(60+100) \\
& A_{2}=80 \\
& A_{3} \rightarrow A_{5}, A_{7} \\
& A_{3}=\frac{1}{2}\left(m_{5}+m_{7}\right) \\
& A_{3}=\frac{1}{2}(140+180) \\
& A_{3}=160 \\
& A_{5} \rightarrow A_{9} \\
& A_{5} \rightarrow m_{9} \\
& A_{5}=220 \\
& A_{7} \rightarrow A_{2} \\
& A_{7} \rightarrow m_{2} \\
& A_{7}=80 \\
& A_{9} \rightarrow A_{10} \\
& A_{9} \rightarrow m_{10} \\
& A_{9}=240 \\
& A_{10} \rightarrow A_{13} \\
& A_{10} \rightarrow m_{13} \\
& A_{10}=300 \\
& A_{13} \rightarrow A_{13} \\
& A_{13} \rightarrow m_{13} \\
& A_{13}=300
\end{aligned}
$$

\section{Bidang Keseluruhan}

$A_{1} \rightarrow A_{1}, A_{1}, A_{2}$

$A_{1}=\frac{1}{3}\left(m_{1}+m_{1}+m_{2}\right)$

$A_{1}=\frac{1}{3}(115+115+145)$

$A_{1}=125$

$$
\begin{aligned}
& A_{2} \rightarrow A_{3} \\
& A_{2} \rightarrow m_{3} \\
& A_{2}=175 \\
& A_{3} \rightarrow A_{6} \\
& A_{3} \rightarrow m_{6} \\
& A_{3}=265 \\
& A_{4} \rightarrow A_{9} \\
& A_{4} \rightarrow m_{9} \\
& A_{4}=355 \\
& A_{6} \rightarrow A_{6}, A_{8} \\
& A_{6} \rightarrow m_{6}, m_{8} \\
& A_{6}=\frac{1}{2}\left(m_{6}+m_{8}\right) \\
& A_{6}=\frac{1}{2}(265+325) \\
& A_{6}=295 \\
& A_{8} \rightarrow A_{8} \\
& A_{8} \rightarrow m_{8} \\
& A_{8}=325 \\
& A_{9} \rightarrow A_{1} \\
& A_{9} \rightarrow m_{1} \\
& A_{9}=115
\end{aligned}
$$

Tabel 10. Hasil Prediksi Bidang Nurse

\begin{tabular}{ccc}
\hline Tahun & Aktual & Prediksi \\
\hline 2008 & 104 & - \\
2009 & 173 & 170 \\
2010 & 39 & 30 \\
2011 & 47 & 43.3 \\
2012 & 29 & 45 \\
2013 & 48 & 43.3 \\
2014 & 41 & 45 \\
2015 & 66 & 45 \\
2016 & 46 & 50 \\
2017 & 29 & 45 \\
2018 & 31 & 43.3 \\
2019 & - & 43.3 \\
\hline
\end{tabular}

Grafik Hasil Prediksi Bidang Nurse

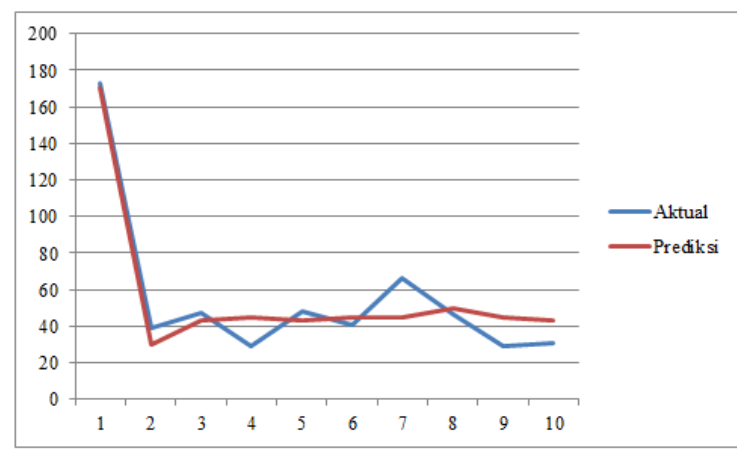

Gambar 2 Grafik Hasil Prediksi Bidang Nurse

Tabel 11. Hasil Prediksi Bidang Care worker

\begin{tabular}{ccc}
\hline Tahun & Aktual & Prediksi \\
\hline 2008 & 104 & - \\
2009 & 189 & 160 \\
2010 & 77 & 80 \\
2011 & 58 & 80 \\
2012 & 72 & 80 \\
\hline
\end{tabular}




\begin{tabular}{ccc}
\hline Tahun & Aktual & Prediksi \\
\hline 2013 & 108 & 80 \\
2014 & 146 & 160 \\
2015 & 212 & 220 \\
2016 & 233 & 240 \\
2017 & 295 & 300 \\
2018 & 298 & 300 \\
2019 & - & 300 \\
\hline
\end{tabular}

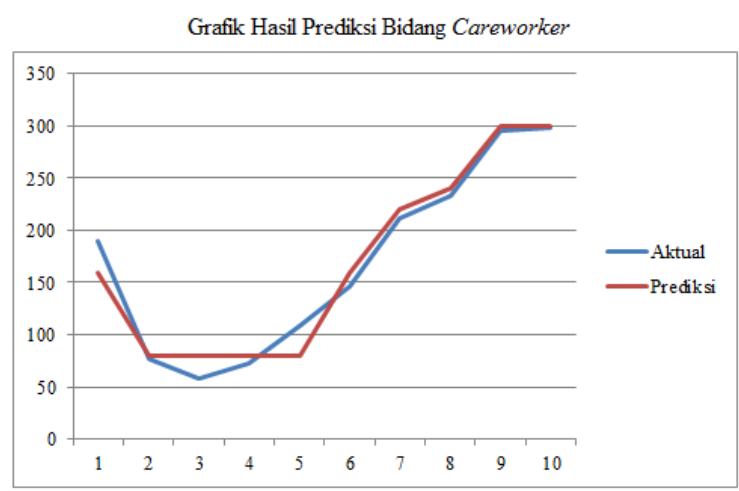

Gambar 3 Grafik Hasil Prediksi Bidang Care worker

Tabel 12. Hasil Prediksi Bidang Keseluruhan

\begin{tabular}{ccc}
\hline Tahun & Aktual & Prediksi \\
\hline 2008 & 208 & - \\
2009 & 362 & 355 \\
2010 & 116 & 115 \\
2011 & 105 & 125 \\
2012 & 101 & 125 \\
2013 & 156 & 125 \\
2014 & 187 & 175 \\
2015 & 278 & 265 \\
2016 & 279 & 295 \\
2017 & 324 & 295 \\
2018 & 329 & 325 \\
2019 & - & 325 \\
\hline
\end{tabular}

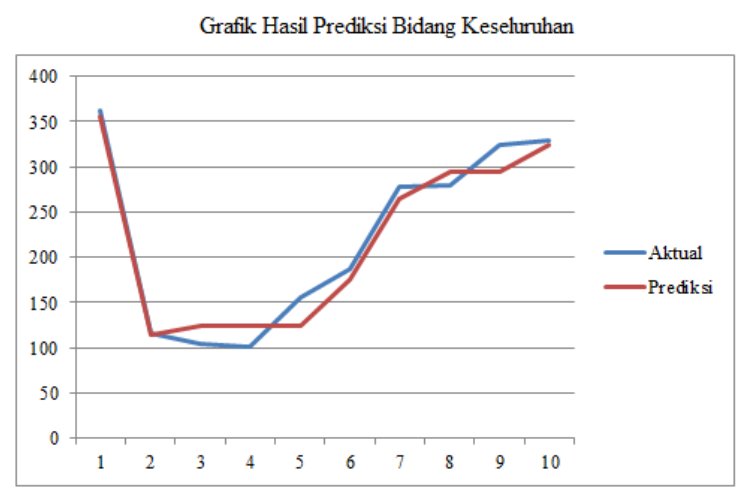

Gambar 4 Grafik Hasil Prediksi Bidang Keseluruhan

Tahap: 6 Evaluasi Kinerja Hasil Prediksi

Dari proses prediksi yang telah dilakukan, maka diperkirakan jumlah penempatan PMI program $G$ to $G$ Jepang tahun 2019 adalah :

Bidang Nurse $=43.3$

Bidang Care worker $=300$

Bidang Keseluruhan $=325$

Proses selanjutnya adalah mencari tingkat kesalahan (error) yang terjadi pada hasil prediksi.

Dalam penelitian ini, digunakan metode Mean Absolute Percentage Error (MAPE) untuk mengetahui hasil kinerja prediksi, dilakukan perhitungan menggunakan rumus 4 (Nugroho dan Purqon, 2015).

$\left|M A P E=\frac{1}{n} \sum_{i-1}^{l}\right| \frac{y_{i}^{\prime}-y_{i}}{y_{i}} \mid x 100$

Di mana $n=$ jumlah data, $y^{\prime}=$ hasil prediksi, $y$ $=$ nilai aktual, $l=$ banyak dimensi data .

Dari hasil proses perhitungan menggunakan rumus MAPE dihasilkan seperti pada Tabel 13.

\begin{tabular}{cccc}
\multicolumn{4}{c}{ Tabel 13. Hasil Proses MAPE } \\
\hline Nurse & Care worker & Keseluruhan \\
\hline MAPE & $24.27 \%$ & $11.29 \%$ & $8.41 \%$ \\
\hline
\end{tabular}

Untuk mengukur ketepatan metode peramalan menggunakan MAPE, maka perlu dilakukan evaluasi dengan mengacu pada Tabel 13 dan 14. Hal tersebut untuk menghindari permasalahan dalam menginterpretasikan ukuran keakuratan relatif terhadap besaran nilai aktual dan nilai hasil prediksi.

Hasil evaluasi ini menunjukkan kemampuan metode prediksi seperti pada Tabel 14. Di mana nilai MAPE $10 \%$ sampai dengan $20 \%$ dapat dikatakan akurasi prediksi baik, nilai MAPE kurang dari $10 \%$ akurasi prediksi dinyatakan sangat baik, nilai $M A P E$ $20 \%$ hingga $50 \%$ akurasi prediksi dinyatakan wajar, sedangkan nilai MAPE lebih dari $50 \%$ akurasi prediksi dinyatakan buruk.

Tabel 14. Nilai MAPE untuk Evaluasi (Chang dkk., 2007)

\begin{tabular}{cc}
\hline Nilai $\boldsymbol{M A P E}$ & Akurasi Prediksi \\
\hline$<10 \%$ & Sangat Baik \\
$10-20 \%$ & Baik \\
$20-50 \%$ & Wajar \\
$>50 \%$ & Buruk \\
\hline
\end{tabular}

Hasil MAPE diperoleh $24.27 \%$ untuk bidang nurse, $11.29 \%$ untuk bidang care worker, dan $8.41 \%$ untuk bidang keseluruhan ditunjukkan Tabel 13.

Untuk hasil uji kinerja prediksi jumlah PMI program $G$ to $G$ Jepang bidang nurse, care worker dan bidang keseluruhan menggunakan model fuzzy time series dan algoritme average-based length dihasilkan nilai $M A P E$ :

$$
\begin{array}{ll}
\text { Bidang nurse } & =20-50 \% \\
\text { Bidang care } \text { worker } & =10-20 \% \\
\text { Bidang keseluruhan } & =<10 \%
\end{array}
$$

maka jika merujuk Tabel 14, tingkat akurasi prediksi termasuk dalam kriteria:

Bidang nurse $=$ Wajar

Bidang care worker $=$ Baik

Bidang keseluruhan $=$ Sangat Baik

\section{KESIMPULAN}

Prediksi dengan menggunakan metode fuzzy time series dan algoritme average-based length 
terbukti efektif untuk mengetahui perkembangan jumlah penempatan PMI program $G$ to $G$ Jepang pada tahun berikutnya. Hal ini ditunjukkan dari hasil prediksi untuk tahun 2019 adalah; bidang nurse = 43.3 , care worker $=300$, dan bidang keseluruhan $=$ 325. Evaluasi hasil akurasi prediksi jumlah PMI program $G$ to $G$ Jepang menggunakan MAPE untuk bidang nurse diperoleh $24.27 \%$ termasuk dalam kriteria wajar, bidang care worker diperoleh $11.29 \%$ termasuk dalam kriteria baik, dan bidang keseluruhan diperoleh $8.41 \%$ termasuk dalam kriteria sangat baik.

Berdasarkan hasil prediksi diatas dapat digunakan sebagai pendukung keputusan bagi manajemen dalam membuat kebijakan terkait persiapan, perencanaan, penjadwalan, penempatan, dan perlindungan terhadap para calon PMI program $G$ to $G$ Jepang di masa mendatang. Dengan demikian pihak BNP2TKI dapat meningkatkan kualitas kinerja sumberdaya manusia dalam memberikan pelayanan terbaik terhadap para calon PMI program $G$ to $G$ Jepang.

Adapun saran untuk penelitian selanjutnya adalah perlu melibatkan beberapa faktor baik internal maupun eksternal, sebagai parameter lengkap dalam proses pengolahan prediksi sehingga dapat menghasilkan hasil yang lebih baik lagi serta disarankan untuk menggunakan data-data histori yang lebih detil dan kompleks agar mendapatkan tingkat keakuratan yang lebih tinggi. Penelitian ke depan diharapkan dapat mengembangkan suatu model yang dapat memprediksi lebih dari satu tahun berikutnya serta perlu menerapkan web based application dan atau mobile based application.

\section{DAFTAR PUSTAKA}

ALADAG, C. H., YOLCU, U., EGRIOGLU, E., DALAR, A. Z., 2012. A new time invariant fuzzy time series forecasting method based on particle swarm optimization. Applied Soft Computing, Vol.12, pp.3291-3299.

ANGGODO, Y.P., MAHMUDY, W.F., 2016. Peramalan Butuhan Hidup Minimum Menggunakan Automatic Clustering dan Fuzzy Logical Relationship. Jurnal Teknologi Informasi dan Ilmu Komputer (JTIIK), Vol.3, No.2, pp.94-102.

BISHT, K., KUMAR, S., 2016. Fuzzy time series forecasting method based on hesitant fuzzy sets. Expert Systems with Applications, Vol.64, pp.557-568.

CHANG, P.-C., WANG, Y.-W., LIU, C.-H., 2007. The development of a weighted evolving fuzzy neural network for PCB sales forecasting. Expert Systems with Applications, Vol.32, pp.86-96.

HEIZER, J., RENDER, B., 2009. Manajemen Operasi. Buku 1 Edisi 9, Jakarta: Salemba Empat.
HUARNG, K.-H., YU, T.H.-K., 2012. Modeling fuzzy time series with multiple observations. Iternational Journal of Innovative Computing, Information and Control, Vol.8, pp.7415-7426.

LU, W., CHEN, X., PEDRYCZ, W., LIU, X., YANG, J., 2015. Using interval information granules to improve forecasting in fuzzy time series. International Journal of Approximate Reasoning, Vo.57, pp.1-18.

NUGROHO, N.A., PURQON, A., 2015. Analisis 9 Saham Sektor Industri di Indonesia Menggunakan Metode SVR. Seminar Kontribusi Fisika, Bandung.

SINGH, P., BORAH, B., 2013. An efficient time series forecasting model based on fuzzy time series. Engineering Applications of Artificial Intelligence, Vol.26, pp.24432457.

WANG, L., LIU, X., PEDRYCZ, W., 2013. Effective intervals determined by information granules to improve forecasting in fuzzy time series. Expert Systems with Applications, Vol.40, pp.5673-5679, issue 14.

XIHAO, S., YIMIN, L., 2008. Average-based fuzzy time series models for forecasting Shanghai compound index. World Journal of Modelling and Simulation, Vol.4, No.2, pp.104-111.

Undang-undang Republik Indonesia nomor 18 tahun 2017 tentang Perlindungan Pekerja Migran Indonesia. Jakarta: Kementerian Hukum dan Hak Asasi Manusia Republik Indonesia.

bnp2tki.go.id, 2018. Retrived from

http://www.bnp2tki.go.id/read/13327/Minat -PMI-Program-G-to-G-ke-Jepang-danKorea-Selatan-Semakin-Tinggi-

Data Penempatan dan Perlindungan PMI. Retrived from

http://www.bnp2tki.go.id/uploads/data/data_05-102018_025400_Laporan_Pengolahan_Data_BNP2TK I_2018_-_SEPTEMBER.pdf 